\title{
Analysis and Evaluation of the Effects of Housing Foundation Activities on Improving the Physical and Social Dimension of Development of Rural Settlements Case Study: Moghan County (Germi) Villages
}

\author{
Firouz Mahdizadeh Kalansara' \\ Mahdi Jahani" \\ Mohammad Ali Ahmadian"I
}

\begin{abstract}
Rural development has a close relationship with structural processes such as social and physical processes. Therefore, in this study, the effects of housing activities in two social and physical dimensions of villages in the city of Germi have been investigated.In order to know about the issues and the results of the preparation and implementation of these projects, it is necessary to study case studies of eligible villages, in this regard, to evaluate the plans of the rural municipality and villagers and the rural ownership document in the villages of Moghan (Germi) 55 villages of the city have been implemented. In this research, descriptive-analytic method has been used based on documentary studies and field operations (questionnaire, interview, etc.). Given the number of villages and the high number of households in rural areas, a sample size of 287 households was determined using the Cochran formula and distributed randomly among the households living in each village. The results of the research show that the relationship between the activities of the Housing Foundation and the social development of the villages is significant (the value is less than 0.05 ), the intensity of the relationship is 0.033 , and the direct and the positive, as well as the relationship between the activities of the Foundation Housing and sustainable development of the villages are meaningful, (the value of which is less than 0.05), the intensity of the relationship is equal to 0.629 , is direct and positive.
\end{abstract}

Keywords: Conducting schemes; Rural housing; Physical and social development; Moghan County (Germi)

I PHD Student, Department of Geography, Mashhad Branch, Islamic Azad University, Mashhad, Iran F.Mahdizadehkalansara@gmail.com

"Assistant Professor, Department of Geography, Mashhad Branch, Islamic Azad University, Mashhad, Iran, Jahanimehdi94@gmail.com

I'Associate Professor, Department of Human Geography, Mashhad Branch, Islamic Azad University, Mashhad, Iran - Ahmadian@ferdowsi.um.ac.ir 


\section{Introduction}

Despite of the continuous decreasing of rural population in the recent decades, a remarkable population of the country lives in the rural regions. In census statistics accomplished in 2016 , around $25.9 \%$ of country population lived in the rural regions. The rural regions play an important role in producing agricultural products, maintaining the environment, national economy, cultural inheritance, the continuation of urban development, political and security considerations. Having no neglect to villages and the role played by them in the national development result in aghabmandegi of developing countries and hurt them in irreparable ways (Molaee Hashtjin, 2002). Schemes and rural developed projects whether in these schemes or short-term schemes via suggested purposes and policies were accomplished to create changes, development and to achieve desirable environmental conditions (monshizade and Rastegar, 2010).

Housing foundation of Islamic Republic of Iran is considered as a structure in recent years as a most important administrator and governmental body with a responsibility to reclaim villages. It is considered as a guiding structure of scheming and physical management in villages and helps rural development physically. Therefore, considering this structure in rural management is an essential different (economic, social and environmentallocation) dimensions. In the rural scheming, the basic purpose is to create conditions in which it is tried to use all facilities in maximum and achieve to the assigned purposes i.e. the development of rural life (Moghadam, 1993). The impacts and results resulted from the analysis of housing foundation activities on the sustainable development of rural settlement can make impacts on sustainable development and necessary data can be provided by identifying strong and weak points to have a better management in a comprehensive and exact consideration of activities accomplished by housing foundation activities particularly in the analyzing of the effects of housing foundation activities (Anabestani, 2012).

Motiee Langroudi has considered the results of implementing the conducting scheme on the environment of residential habitations and the results indicated that this scheme was not successful environmentally. Therefore; the services presented by conducting scheme 
should be reformed and environmental studies should be considered as a priority (Motiee Langroudi, 2010). In considering the economic statistics of implementing the conducting scheme, Azizpour has concluded that to implement this scheme results in enhancing the investment, employment and income for the rural (Azizpour, 2011).

In an evaluation on the space-physical impacts of conducting schemes in Pirkandi village of Khoy County, Mobarak concluded that the poor management in presenting loans to destroy housing units, abandoning an executive work for a short time, unsuitable discharging of surface waters in sidewalks, lack of complete asphalt and channels of alleys and streets, stimulated transferring of housing lands to several individuals, unequal development of village texture, not asking the rural opinions and lo participation from the rural in providing and implementing phases of conducting schemes are the most important obstacles of implementing the conducting schemes in Pirkandi (Mobarak, 2011). The results of a study on physical development of rural habitations via a sustainable development approach accomplished by Pourtaheri and Naghavi indicate that by considering the applied structural problems of rural areas, the development of rural habitations face with some challenges such as poverty, unequal income, rural migrations and discharging of villages, lack of space-physical management and high vulnerability of rural habitations in a great extent. It is concluded that there is a weak relationship between sustainable approaches and physical development (Pourtaheri and Naghavi, 2011).

Anabestani has evaluated the conducting schemes and studied the role played by these schemes in physical development of villages in Jahrom County. The results suggested that the conducting scheme has imposed the highest and the lowest impact on renovating the rural pedestrian network and land use; respectively (Anabestani, 2012). Eslami et al. in the analysis of producing, confirmation and implementing processes of rural conducting scheme, desirability in Mazandaran province presented that the components of rural conducting scheme services did not meet the rural needs enough and some criteria were assigned to provide, collect and reform counselors in a suitable way (Ghorban Eslamirad and Yaser Ghasemi, 2013).

Among the 706000901 population of Moghan County (Germi), 45000279 (59\%) lives in the villages (Statistical centre of Iran, 2016). By considering that 59\% of the rural live in 
rural habitations and in order to enhance qualitative and quantitative indices of rural habitations, physical organization of rural habitations to make social and economic justice should be considered. Therefore; by considering the presence and services and implementing of great projects to organize space-physical rural habitations by housing foundation of Islamic Republic, there is not much evidence on changes implemented by this revolutionary foundation.

According to the purposes of study, the present study is an applied one and the results can be applied in planning. Three dimensions for Housing Foundations activities (providing and implement of conducting scheme, rural housing and the rural title deed) and two dimensions for rural sustainable development (social and physical) were considered to achieve favorable results and to evaluate the Housing Foundations activities on sustainable development of rural habitations from case studies.

Figure 1 - The concept model of effects of Housing Foundations activities on social and physical development of rural habitations

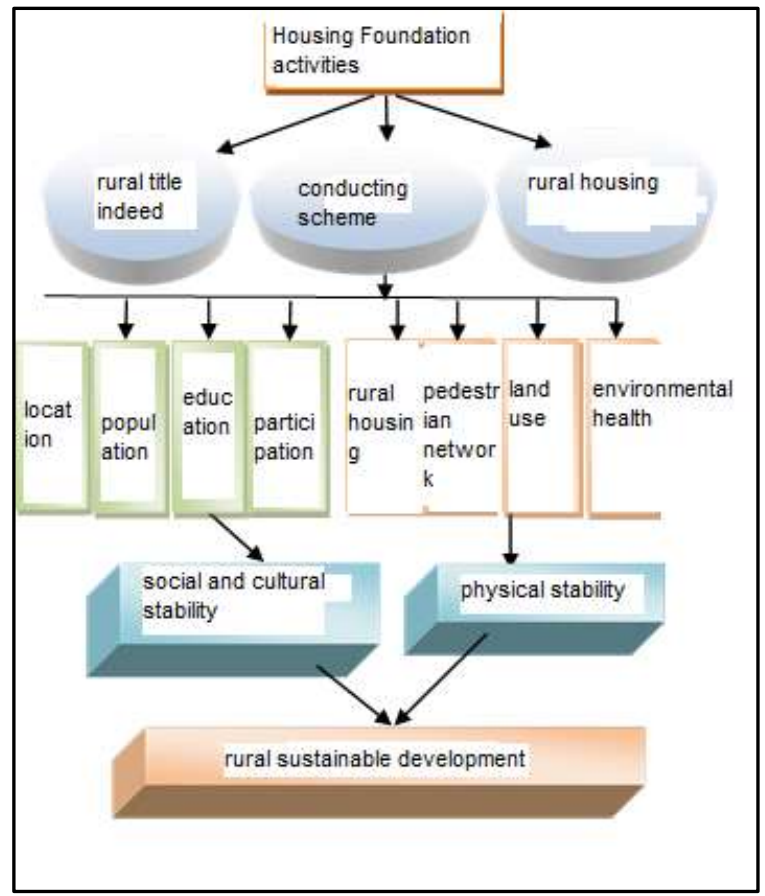




\section{Material and methods}

\subsection{The situation of case study boundary}

Germi is bounded from north to Bileh Savar and Parsabad from north, to Kaleybar and Ahar from west (East Azerbaijan), to Meshgin Shar from south and to Azerbaijan Republic- Jalilababd and Yardimli from east. It is bounded to Salavat mountains from south, to Khoroslou mountains from north, to Darehroud river from west and to Balehrod from east. Based on administrative division, Moghan is $2049 \mathrm{~km}^{2}$ (figure 2).

Figure 2 - The situation of case study boundary

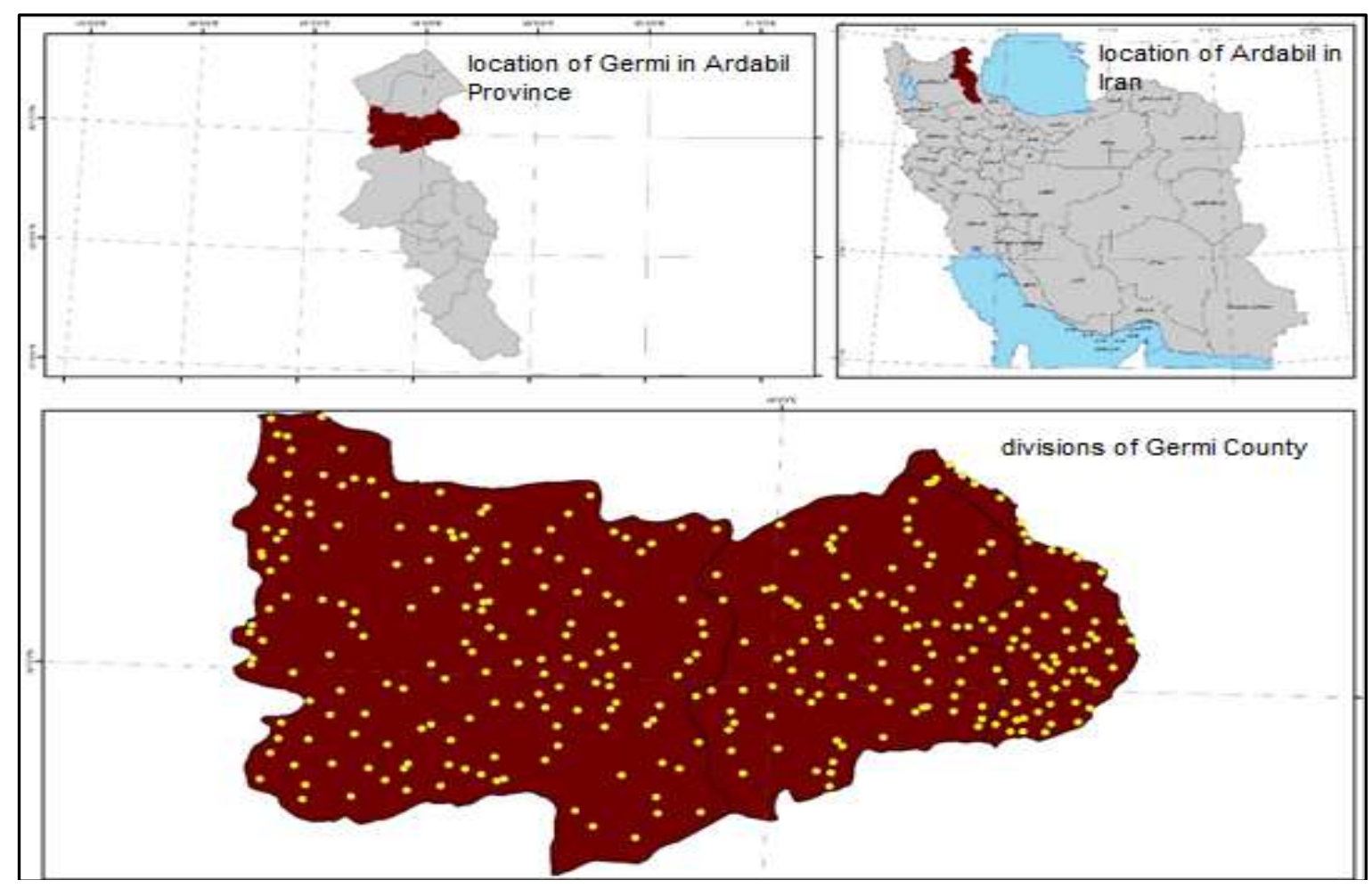

\section{Methodology}

A descriptive method was applied to study the impact of Housing Foundation activities on the development of rural habitations. By considering the research question, the present study is a survey, applied and descriptive-analytical based on the completion of questionnaire, purpose and methods; respectively. The statistical society is composed of 
villages of Germi County. Among 317 villages, 55 ones were selected in which most activities included providing of conducting scheme, implementing of conducting scheme, issuing title deed and strengthening of houses in Moghan (Germi) County. At first, the qualified villages were classified in 4 groups, then according to the abundance $20 \%$ of villages (12 villages in each group) were selected randomly. Cochran formula was applied to select the sample volume. Via a variance resulted from pre-test, $\mathrm{N}=287$ was calculated which was divided between families of villages via a systematic random method. First, provided schemes and evidences related to implement were studied, then the data on the rural views and influential people was collected through questionnaires. Via an exploratory method of effective variants on implementing of schemes were determined to provide a proper questionnaire. When the initial test was completed and reliability and validity were evaluated via $10 \%$ of the real sample, the final questionnaire provided. SPSS software was applied in the final analysis of inferential statistics particularly correlation, multi-variant regression.

\section{Results}

Via applying some questions in Likert format, two variants of Housing Foundation activities and sustainable development were considered. Both of these variants conclude some dimensions composed of components presented in the following table with abundance of each item with percentage in each question.

Table 1 - The abundance of selecting items of questions in questionnaire of part two in the evaluation of Foundation activities

\begin{tabular}{|c|c|c|c|c|c|c|c|c|}
\hline Dimension & Component & Questions & Index & Too little & Little & Average & High & Too high \\
\hline \multirow{3}{*}{$\begin{array}{l}\text { Rural } \\
\text { housing }\end{array}$} & \multirow{3}{*}{$\begin{array}{c}\text { House } \\
\text { reformation }\end{array}$} & \multirow{2}{*}{$\begin{array}{l}\text { The durability and } \\
\text { quality of houses built by } \\
\text { foundation }\end{array}$} & Abundance & 2 & 2 & 26 & 123 & 142 \\
\hline & & & Percentage & $0 / 7$ & $0 / 7$ & $8 / 8$ & $41 / 7$ & $48 / 1$ \\
\hline & & $\begin{array}{l}\text { Satisfaction from the } \\
\text { facade of houses built by } \\
\text { the Foundation }\end{array}$ & Abundance & 2 & 0 & 48 & 128 & 117 \\
\hline
\end{tabular}




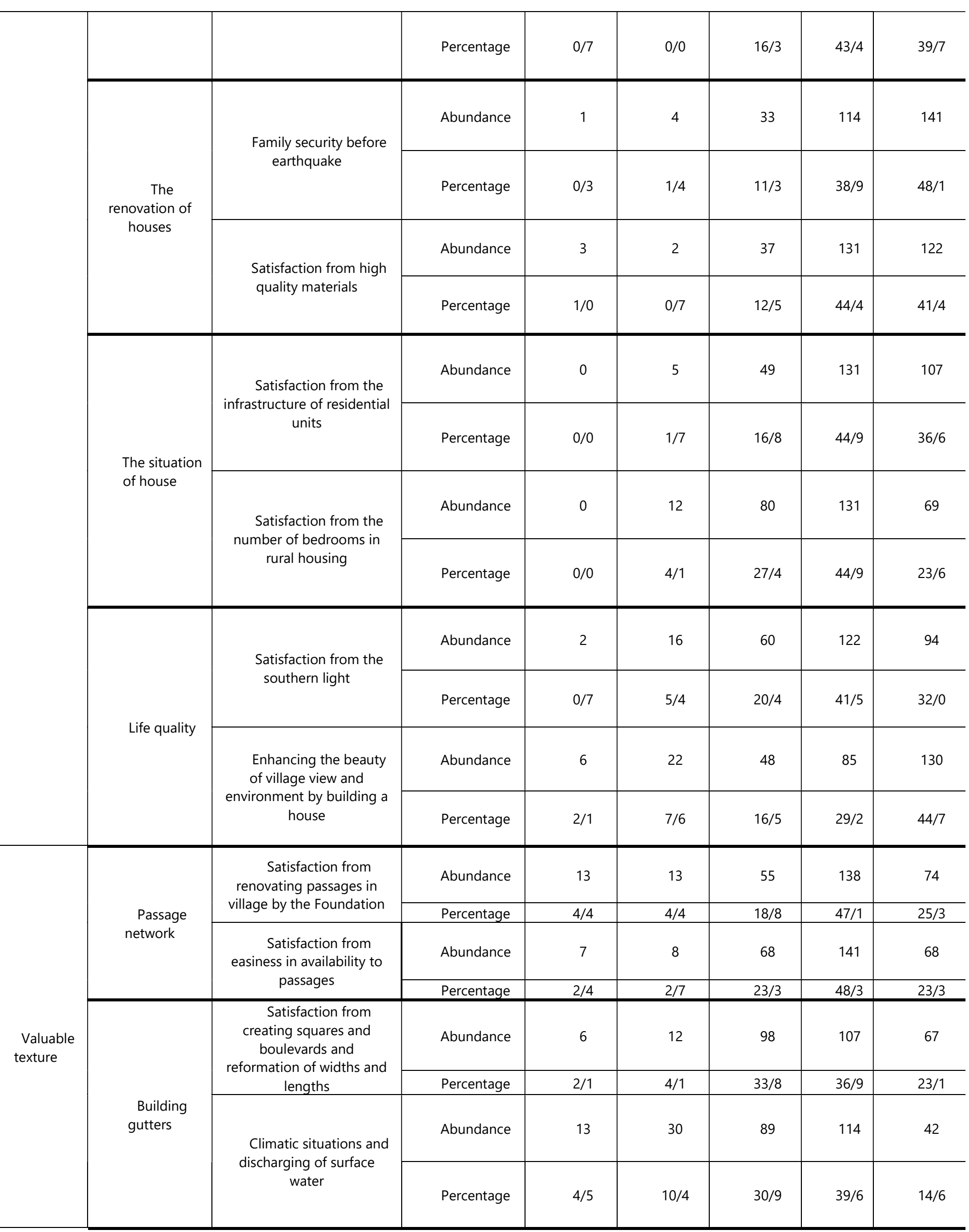


Analysis and Evaluation of the Effects of Housing Foundation Activities on Improving the Physical and Social

\begin{tabular}{|c|c|c|c|c|c|c|c|c|}
\hline & \multirow{4}{*}{$\begin{array}{l}\text { Developmen } \\
\text { t direction }\end{array}$} & \multirow{2}{*}{$\begin{array}{l}\text { Satisfaction from land } \\
\text { use in physical } \\
\text { development of village }\end{array}$} & Abundance & 1 & 17 & 119 & 127 & 27 \\
\hline & & & Percentage & $0 / 3$ & $5 / 8$ & $40 / 9$ & $43 / 6$ & $9 / 3$ \\
\hline & & \multirow{2}{*}{$\begin{array}{l}\text { Preserving of village } \\
\text { physical identity in building } \\
\text { residential units }\end{array}$} & Abundance & 24 & 56 & 109 & 68 & 37 \\
\hline & & & Percentage & $8 / 2$ & $19 / 0$ & $37 / 1$ & $23 / 1$ & $12 / 6$ \\
\hline & \multirow{4}{*}{$\begin{array}{l}\text { Valuable } \\
\text { texture }\end{array}$} & \multirow{2}{*}{$\begin{array}{l}\text { Satisfaction from } \\
\text { preserving, reviving and } \\
\text { renovating of textures and } \\
\text { skeleton of village }\end{array}$} & Abundance & 3 & 37 & 116 & 92 & 42 \\
\hline & & & Percentage & $1 / 0$ & $12 / 8$ & $40 / 0$ & $31 / 7$ & $14 / 5$ \\
\hline & & \multirow{2}{*}{$\begin{array}{l}\text { Preserving of village } \\
\text { physical identity in building } \\
\text { residential units }\end{array}$} & Abundance & 11 & 51 & 90 & 98 & 41 \\
\hline & & & Percentage & $3 / 8$ & $17 / 5$ & $30 / 9$ & $33 / 7$ & $14 / 1$ \\
\hline \multirow{9}{*}{$\begin{array}{l}\text { Title } \\
\text { Deed }\end{array}$} & \multirow{4}{*}{ Economic } & \multirow{2}{*}{$\begin{array}{l}\text { Price increasing of } \\
\text { lands and houses by } \\
\text { issuing a title deed }\end{array}$} & Abundance & 3 & 2 & 30 & 81 & 175 \\
\hline & & & Percentage & $0 / 1$ & $0 / 7$ & $10 / 3$ & $27 / 8$ & $60 / 1$ \\
\hline & & $\begin{array}{l}\text { The effectiveness of } \\
\text { issuing the rural title deed }\end{array}$ & Abundance & 7 & 12 & 58 & 120 & 97 \\
\hline & & and facilities & Percentage & $2 / 4$ & $4 / 1$ & $19 / 7$ & $40 / 8$ & $33 / 0$ \\
\hline & \multirow{5}{*}{ Social } & \multirow{3}{*}{$\begin{array}{l}\text { Effect of issuing title } \\
\text { deed in helping }\end{array}$} & & & & & & \\
\hline & & & Abundance & 5 & 12 & 42 & 94 & 141 \\
\hline & & & Percentage & $1 / 7$ & $4 / 1$ & $14 / 3$ & $32 / 0$ & $48 / 0$ \\
\hline & & \multirow{2}{*}{$\begin{array}{l}\text { Decreasing of property } \\
\text { disputes by issuing title } \\
\text { deed }\end{array}$} & Abundance & 2 & 4 & 24 & 53 & 212 \\
\hline & & & Percentage & $0 / 7$ & $1 / 4$ & $8 / 1$ & $18 / 0$ & $71 / 9$ \\
\hline
\end{tabular}

By considering the quality of new houses, too high level can be observed $(48.14 \%)$ in evaluation. By considering the questions, satisfaction from facet of houses built by Housing Foundation can be considered which is reported to be too high in most evaluations (43.39\%). By considering family security before earthquake, too high level can be observed in houses built by Housing Foundation (48.12\%). In considering the questions on satisfaction of the rural about the quality of materials, too high satisfaction is stated by people in most cases (44.41\%). When questions on satisfaction from infrastructure of housing units are considered, an average satisfaction is stated in most cases (44.86\%). By considering the questions on satisfaction from exploiting (using) southern light, too high satisfaction is 
observed in most cases (41.5\%). By a look at enhancing the beauty of country vies and environments, too high level can be observed in most cases (47.1\%). When questions on satisfaction from renovation of pedestrian network by Housing Foundation are considered, too high satisfaction is reported in most evaluations (47.1\%). By considering the questions on easiness in availability for pedestrians, too high satisfaction can be stated in most evaluations (48.29\%). By considering the questions on creating squares, boulevards and reformation of width and length of passages, too high level of satisfaction can be observed in most cases (36.9\%). Via a look at the climatic situations and discharging of surface water, an average satisfaction can be evaluated in most cases (39.58\%). By considering satisfaction from land use in physical development of village, an average satisfaction as evaluated in most cases (43.64\%). Via a look at changing agricultural lands to non-agricultural ones, too high level of satisfaction as evaluated (37.07\%). By considering satisfaction from preserving, reviving and renovating of textures and skeleton of village by the Foundation, too high level of satisfaction can be observed (40\%). Via considering the preserve of physical skeleton identity of village in building residential units, too high level of satisfaction has been reported (33.68\%). By considering the price increasing in houses by issuing a title deed, too high level of satisfaction has been evaluated (60.14\%). By considering the question on effectiveness of issuing the rural title deed on attracting investment and facilities, too high satisfaction can be observed in most evaluations (40.82\%). Via considering the effectiveness of issuing the rural title deed, too high level of satisfaction has been stated in most evaluation accomplished (47.96\%). By a look at decreasing of property disputes by issuing title deed, too high level has been reported (71.86\%).

(Continue...)

Table 2 - The abundance of selecting items of questions in questionnaire of part two in the evaluation of sustainable development 
Analysis and Evaluation of the Effects of Housing Foundation Activities on Improving the Physical and Social Dimension of Development of Rural Settlements Case Study: Moghan County (Germi) Villages

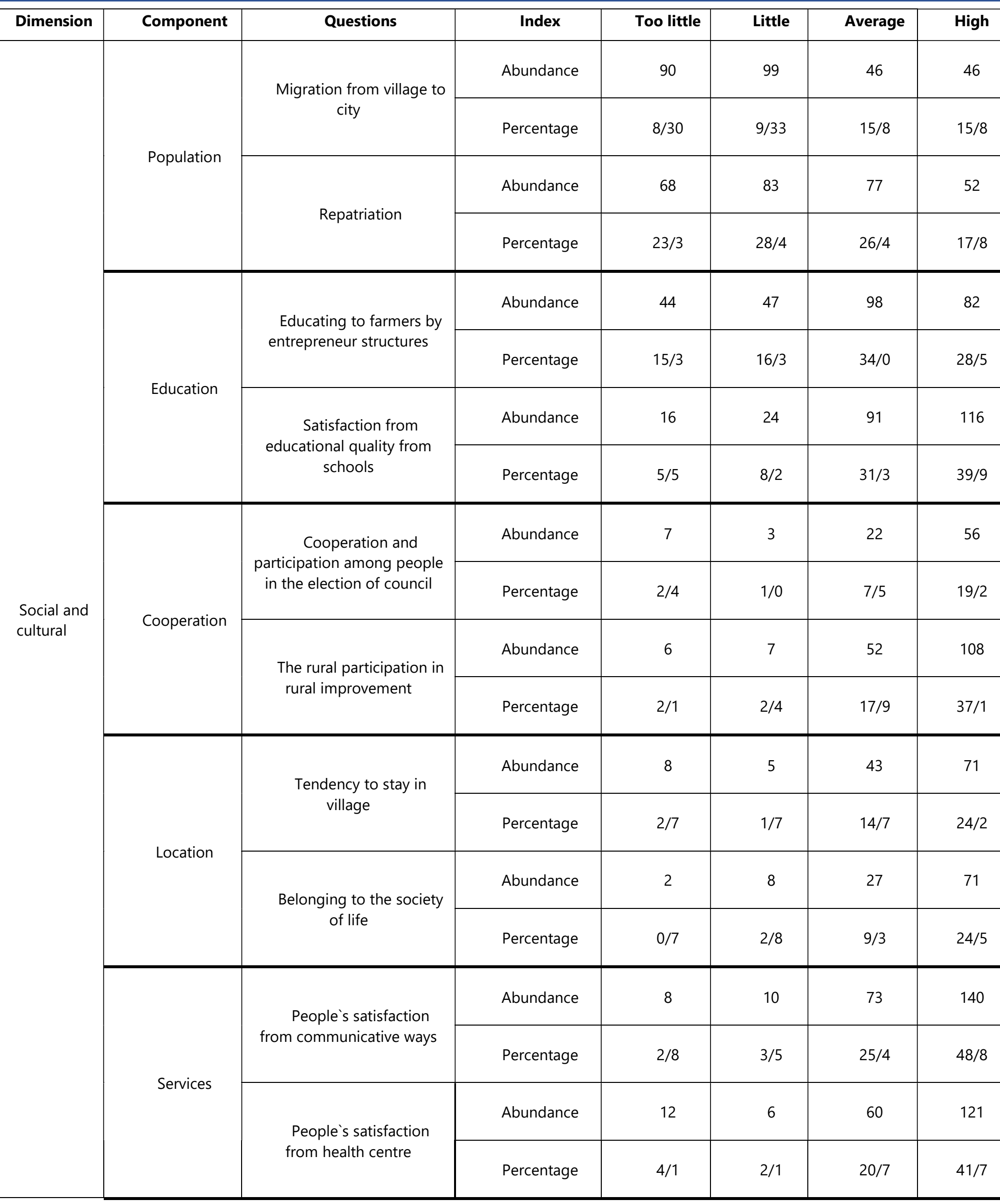




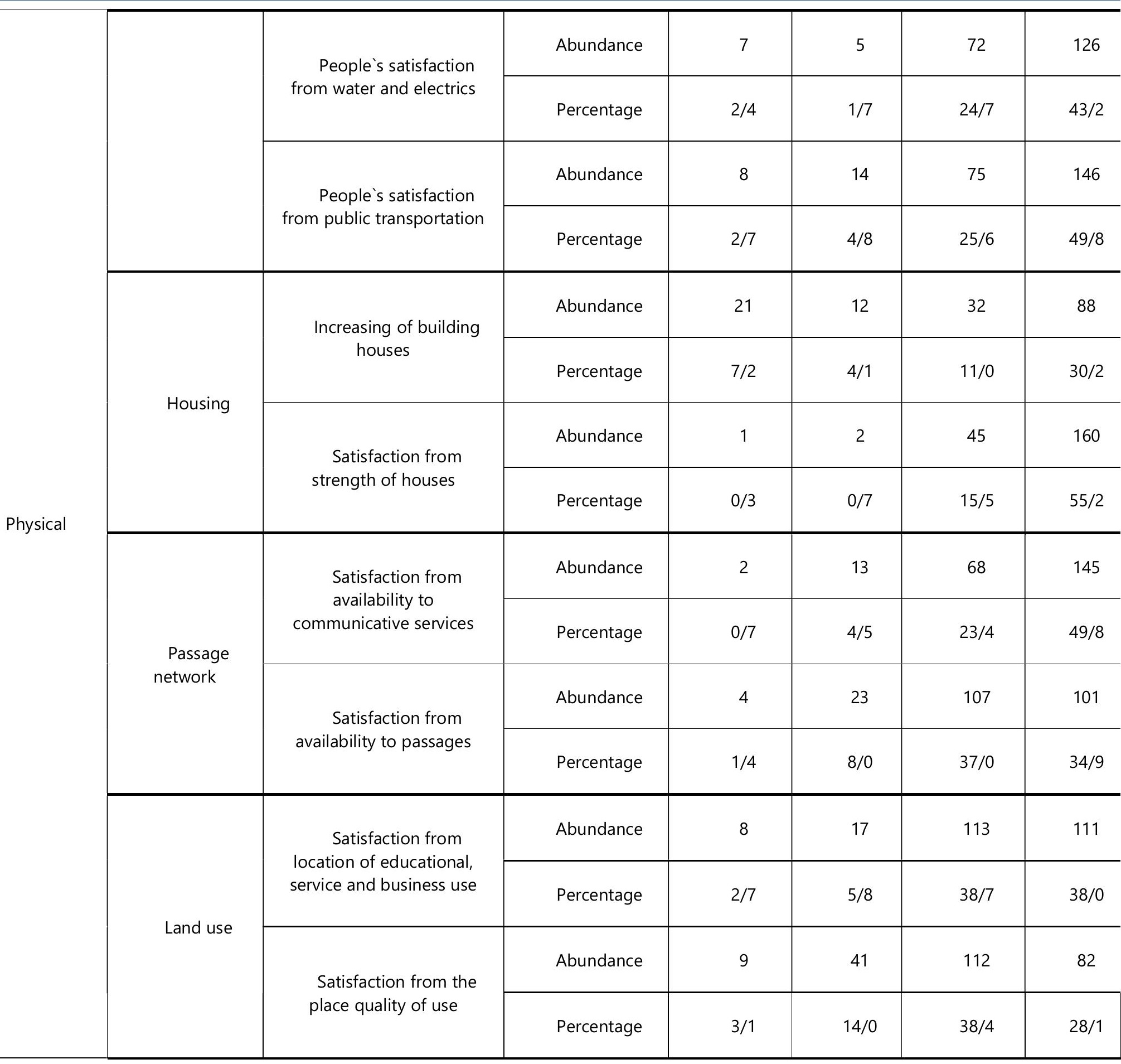

By considering migration from village to town, too high level can be observed (33.9\%) in evaluation. By considering repatriation, too high level has been reported in most evaluations (28.42\%). By considering the item of educating to farmers by entrepreneur structures, too high level can be observed (34.03\%). In considering the questions on Satisfaction from educational quality from schools, an average satisfaction is stated by people in most cases (39.86\%). When questions on cooperation and participation among 
people in the election of council are considered, too high satisfaction is observed in most cases (69.86\%). By considering the questions on the rural participation in rural development, too high satisfaction is announced in most cases (40.55\%). By a look at the item of tendency to stay in village, too high level has been evaluated in most cases (56.66\%). When questions on belonging to the society of life are considered, too high satisfaction is reported in most evaluations (62.76\%). By considering the questions on people's satisfaction from communicative ways, an average satisfaction has been stated in most evaluations (48.78\%). By considering the questions on People's satisfaction from health centre, an average satisfaction has been stated in most cases (41.72\%). Via a look at People`s satisfaction from water and electrics, an average satisfaction can be observed in most cases (43.15\%). By considering People's satisfaction from public transportation, too much satisfaction has been evaluated in most cases (49.83\%).

Via a look at the question of increasing of building houses, too high level of satisfaction has been announced in most cases (47.42\%). By considering satisfaction from strength of houses, an average satisfaction can be stated in most cases (55.17\%). Via considering satisfaction from availability to communicative services, too high level of satisfaction has been reported (49.83\%). By considering satisfaction from availability to passages, too high level of satisfaction has been evaluated in most cases (37.02\%). By considering satisfaction from location of educational, service and business use, too high level of satisfaction has been stated in most evaluation has been announced(38.7\%). By a look at satisfaction from the place quality of use, too high level has been evaluated (38.36\%).

Here, the descriptive indices of research variants have been presented separately for sample villages. By considering the evaluated average for this variant and its components, it is considered that Bill Dashi in all components and in this variant has got the most average and the best situation.

(Continue...)

Table 3 - The average of rural housing variant and dimensions in villages separately 


\begin{tabular}{c|c|c|c|c|c}
\hline Village & Services & Location & Situation & Quality & Cooperation \\
\hline Omaslan & 4.71 & 4.55 & 4.19 & 4.62 & 4.52 \\
\hline $\begin{array}{c}\text { Gadeh } \\
\text { Kahriz }\end{array}$ & 4.47 & 4.53 & 3.97 & 4.57 & 4.38 \\
\hline Gilarlu & 4.37 & 4.50 & 3.77 & 4.37 & 4.25 \\
\hline Azadlu & 4.44 & 4.44 & 4.29 & 4.35 & 4.38 \\
\hline $\begin{array}{c}\text { Parchin-e- } \\
\text { Sofla }\end{array}$ & 4.38 & 4.10 & 4.13 & 3.92 & 4.13 \\
\hline Tikanloo & 3.98 & 4.20 & 3.59 & 3.70 & 3.87 \\
\hline Hacha Kand & 4.21 & 4.21 & 3.88 & 3.50 & 3.95 \\
\hline Qasem & 3.98 & 4.13 & 3.75 & 3.73 & 3.90 \\
\hline Kandi & 4.82 & 4.91 & 4.68 & 4.64 & 4.76 \\
\hline Kalan Sara & 4.13 & 4.30 & 4.07 & 3.99 & 4.12 \\
\hline Ziveh & 4.26 & 4.06 & 3.94 & 3.80 & 4.47 \\
\hline Aniye Vosta & 4.41 & 4.36 & 4.61 & 4.50 & \\
\hline Bildashi & 4.82 & & & & \\
\hline
\end{tabular}

The conducting scheme and its components have been presented in all villages, separately based on averages. By considering the evaluated averages for this variant and its components, it is conducted that Bill Dashi villages in all variants except shabakeye maaber (Omaslan is a village with the best situation) have got the most average and the best situation.

Table 4 - The average of conducting scheme and its dimensions in villages separately

\begin{tabular}{c|c|c|c|c|c}
\hline Village & $\begin{array}{r}\text { Pedestria } \\
\text { n network }\end{array}$ & $\begin{array}{r}\text { Buildin } \\
\text { g gutters }\end{array}$ & $\begin{array}{c}\text { Developmen } \\
\text { t direction }\end{array}$ & $\begin{array}{c}\text { Valuabl } \\
\text { e texture }\end{array}$ & $\begin{array}{c}\text { Conductin } \\
\text { g scheme }\end{array}$ \\
\hline Omasla & 4.26 & 3.86 & 3.21 & 3.38 & 3.68 \\
$\mathrm{n}$ & & & & & \\
\hline
\end{tabular}




\begin{tabular}{|c|c|c|c|c|c|}
\hline $\begin{array}{l}\text { Gadeh } \\
\text { Kahriz }\end{array}$ & 3.93 & 3.53 & 3.10 & 2.60 & 3.29 \\
\hline Gilarlu & 4.23 & 3.87 & 3.33 & 3.03 & 3.62 \\
\hline Azadlu & 4.15 & 3.91 & 3.26 & 3.35 & 3.67 \\
\hline $\begin{array}{l}\text { Parchin- } \\
\text { e-Sofla }\end{array}$ & 3.90 & 3.50 & 3.10 & 3.04 & 3.39 \\
\hline $\begin{array}{l}\text { Tikanlo } \\
\text { o }\end{array}$ & 3.69 & 3.48 & 3.30 & 3.06 & 3.38 \\
\hline $\begin{array}{l}\text { Hacha } \\
\text { Kand }\end{array}$ & 4.00 & 3.79 & 3.16 & 3.13 & 3.52 \\
\hline $\begin{array}{l}\text { Qasem } \\
\text { Kandi }\end{array}$ & 3.38 & 3.22 & 3.20 & 3.18 & 3.25 \\
\hline $\begin{array}{l}\text { Kalan } \\
\text { Sara }\end{array}$ & 4.23 & 3.86 & 3.37 & 3.23 & 3.67 \\
\hline Ziveh & 3.67 & 3.45 & 3.50 & 3.46 & 3.51 \\
\hline $\begin{array}{l}\text { Aniye } \\
\text { Vosta }\end{array}$ & 3.52 & 3.41 & 3.68 & 3.86 & 3.61 \\
\hline Bildashi & 3.68 & 4.05 & 4.00 & 4.18 & 3.98 \\
\hline
\end{tabular}

In table 5, the average of title deed and its components in all villages has been presented separately. By considering the evaluated averages for this variant and its components, Parchin Sofla has got the highest average and the best situation in economic components while Azadlou has the highest average and the best location in social component and title deed.

(Continue...)

Table 5 - The average of title deed and its dimensions in villages separately 


\begin{tabular}{l|c|c|c}
\hline \multicolumn{1}{c|}{ Village } & Economical & Social & $\begin{array}{r}\text { Title } \\
\text { indeed }\end{array}$ \\
\hline Omaslan & 4.50 & 4.43 & 4.46 \\
\hline Gadeh Kahriz & 4.07 & 4.50 & 4.28 \\
\hline Gilarlu & 4.17 & 4.30 & 4.23 \\
\hline Azadlu & 4.44 & 4.88 & 4.66 \\
\hline Parchin-e-Sofla & 4.52 & 4.71 & 4.61 \\
\hline Tikanloo & 4.13 & 4.20 & 4.17 \\
\hline $\begin{array}{l}\text { Hacha Kand } \\
\text { Darmanlu }\end{array}$ & 4.39 & 4.61 & 4.50 \\
\hline Qasem Kandi & 3.95 & 4.20 & 4.08 \\
\hline Kalan Sara & 4.03 & 4.34 & 4.19 \\
\hline Ziveh & 4.12 & 4.07 & 4.10 \\
\hline Aniye Vosta & 4.07 & 4.55 & 4.31 \\
\hline Bildashi & 4.50 & 4.77 & 4.64 \\
\hline
\end{tabular}

In table 6, the average of physical development and its components in all case study villages has been presented separately. By considering the evaluated averages for this variant and its components, Bill Dashi in all components except housing (Omaslan has got the best situation) has got the highest average and the best situation.

Table 6 - The average of physical development and its components in all case study villages separately

\begin{tabular}{l|c|c|c}
\hline \multicolumn{1}{c|}{ Village } & Economical & Social & Indeed \\
\hline Omaslan & 4.50 & 4.43 & 4.46 \\
\hline Gadeh Kahriz & 4.07 & 4.50 & 4.28 \\
\hline Gilarlu & 4.17 & 4.30 & 4.23 \\
\hline Azadlu & 4.44 & 4.88 & 4.66 \\
\hline Parchin-e-Sofla & 4.52 & 4.71 & 4.61 \\
\hline
\end{tabular}




\begin{tabular}{c|c|c|c}
\hline Tikanloo & 4.13 & 4.20 & 4.17 \\
\hline $\begin{array}{c}\text { Hacha Kand } \\
\text { Darmanlu }\end{array}$ & 4.39 & 4.61 & 4.50 \\
\hline Qasem Kandi & 3.95 & 4.20 & 4.08 \\
\hline Kalan Sara & 4.03 & 4.34 & 4.19 \\
\hline Ziveh & 4.12 & 4.07 & 4.10 \\
\hline Aniye Vosta & 4.07 & 4.55 & 4.31 \\
\hline Bildashi & 4.50 & 4.77 & 4.64 \\
\hline
\end{tabular}

In table 7 , the average of social and cultural variant and their components in all case study villages has been presented separately. By considering the evaluated averages for this variant and its components, Omaslan in terms of population and social and cultural, Gadeh Kahriz in education, Hacha Kand Darmanlu in participation and Bill Dashi in services) have got the best situation.

Table 7 - The average of social and cultural variant and their components in all case study villages

\begin{tabular}{c|c|c|c|c|c|c}
\hline Village & $\begin{array}{c}\text { Populati } \\
\text { on }\end{array}$ & $\begin{array}{c}\text { Educati } \\
\text { on }\end{array}$ & $\begin{array}{c}\text { Participati } \\
\text { on }\end{array}$ & $\begin{array}{c}\text { Locati } \\
\text { on }\end{array}$ & $\begin{array}{c}\text { Servic } \\
\text { es }\end{array}$ & $\begin{array}{c}\text { Soci } \\
\text { al and } \\
\text { cultura } \\
\text { I }\end{array}$ \\
\hline Omasl & $3 / 79$ & $3 / 55$ & $4 / 62$ & $4 / 33$ & $3 / 62$ & $3 / 98$ \\
an & & & & & & \\
\hline Gadeh & $2 / 73$ & $3 / 77$ & $4 / 33$ & $4 / 57$ & $4 / 22$ & $3 / 92$ \\
\hline Gahriz & $3 / 16$ & $253 /$ & $4 / 29$ & $4 / 09$ & $3 / 94$ & $3 / 75$ \\
\hline Azadlu & $1 / 94$ & $3 / 53$ & $4 / 35$ & $4 / 50$ & $3 / 86$ & $3 / 64$ \\
\hline Parchi & $2 / 35$ & $3 / 35$ & $4 / 54$ & $4 / 67$ & $3 / 78$ & $3 / 74$ \\
n-e-Sofla & & & & & & \\
\hline
\end{tabular}




\begin{tabular}{c|c|c|c|c|c|c}
\hline Tikanlo & $2 / 28$ & $3 / 13$ & $4 / 22$ & $4 / 09$ & $3 / 66$ & $3 / 48$ \\
\hline $\begin{array}{c}\text { Hacha } \\
\text { Kand } \\
\text { Darmanlu }\end{array}$ & $1 / 84$ & $3 / 04$ & $3 / 73$ & $4 / 75$ & $3 / 66$ & $3 / 40$ \\
\hline $\begin{array}{c}\text { Qasem } \\
\text { Kandi }\end{array}$ & $2 / 68$ & $3 / 27$ & $4 / 14$ & $4 / 10$ & $3 / 84$ & $3 / 61$ \\
\hline $\begin{array}{c}\text { Kalan } \\
\text { Sara }\end{array}$ & $1 / 91$ & $23 / 3$ & $4 / 67$ & $4 / 40$ & $3 / 94$ & $3 / 64$ \\
\hline Ziveh & $2 / 70$ & $3 / 22$ & $4 / 23$ & $4 / 27$ & $3 / 86$ & $3 / 66$ \\
\hline Aniye & $1 / 48$ & $2 / 64$ & $4 / 45$ & $4 / 70$ & $3 / 67$ & $3 / 39$ \\
Vosta & $1 / 91$ & $2 / 68$ & $4 / 50$ & $4 / 23$ & $4 / 59$ & $3 / 58$ \\
\hline Bildash & & & & & & \\
\hline
\end{tabular}

By considering the importance and dependence of Housing Foundation activities on the development of rural habitations, the relationship between Housing Foundation activities and social development of villages will be considered in the whole sample and in all villages separately.

Table 8 - The results of correlation between social activities of villages and Housing Foundation activities in all villages

\begin{tabular}{l|c|c|c}
\hline \multicolumn{1}{c|}{ Village } & $\begin{array}{c}\text { Correlation } \\
\text { coefficient }\end{array}$ & P value & Total \\
\hline Omaslan & $* * 609$. & $0 / 003$ & 21 \\
\hline Gadeh Kahriz & $* 535$. & $0 / 040$ & 15 \\
\hline Gilarlu & $0 / 420$ & $0 / 119$ & 15 \\
\hline Azadlu & $0 / 309$ & $0 / 228$ & 17 \\
\hline Parchin-e-Sofla & $0 / 294$ & $0 / 164$ & 24 \\
\hline Tikanloo & $* 398$. & $0 / 040$ & 27 \\
\hline
\end{tabular}




\begin{tabular}{l|c|c|c}
\hline $\begin{array}{c}\text { Hacha Kand } \\
\text { Darmanlu }\end{array}$ & $0 / 068-$ & $0 / 730$ & 28 \\
\hline Qasem Kandi & $* * 588$. & $0 / 001$ & 30 \\
\hline Kalan Sara & $0 / 014-$ & $0 / 937$ & 35 \\
\hline Ziveh & $* * 609$. & $0 / 000$ & 50 \\
\hline Aniye Vosta & $* 554$. & $0 / 007$ & 22 \\
\hline Bildashi & $0 / 012$ & $0 / 973$ & 11 \\
\hline Total & $0 / 330 * *$ & $0 / 000$ & 295 \\
\hline
\end{tabular}

As you can observe in the above table, there is a significant, positive and direct relationship between Housing Foundation activities and social development of villages in all whole of sample and in Omaslan, Gadeh Kahriz, Tikanloo, Qasem Kandi, Ziveh and Aniye Vosta. Therefore, as activities by Housing Foundation increases, social development will increase too and vice versa.

There is a significant, positive and direct relationship between Housing Foundation activities and physical development of villages in all whole of sample and in Omaslan, Azadlu, Parchin-e-Sofla, Tikanloo, Hacha Kand Darmanlu, Ziveh and Aniye Vosta. Therefore, as activities by Housing Foundation increases, physical development will increase too and vice versa (table 9).

Table 9 - The results of correlation between physical activities of villages and Housing Foundation activities in all villages

\begin{tabular}{l|c|c|c}
\hline \multicolumn{1}{c|}{ Village } & $\begin{array}{c}\text { Correlation } \\
\text { coefficient }\end{array}$ & P value & Total \\
\hline Omaslan & $.738^{\star \star}$ & $0 / 000$ & 21 \\
\hline Gadeh Kahriz & $0 / 324$ & $0 / 239$ & 15 \\
\hline Gilarlu & $0 / 196$ & $0 / 484$ & 15 \\
\hline Azadlu & $.775^{\star \star}$ & $0 / 000$ & 17 \\
\hline Parchin-e-Sofla & $.580^{\star *}$ & $0 / 003$ & 24 \\
\hline Tikanloo & $.773^{\star *}$ & $0 / 000$ & 27 \\
\hline
\end{tabular}




\begin{tabular}{l|c|c|c}
\hline $\begin{array}{c}\text { Hacha Kand } \\
\text { Darmanlu }\end{array}$ & $.614^{* *}$ & $0 / 001$ & 28 \\
\hline Qasem Kandi & $0 / 202$ & $0 / 284$ & 30 \\
\hline Kalan Sara & $.516^{\star *}$ & $0 / 002$ & 35 \\
\hline Ziveh & $.646^{\star *}$ & $0 / 000$ & 50 \\
\hline Aniye Vosta & $.795^{\star *}$ & $0 / 000$ & 22 \\
\hline Bildashi & $0 / 012$ & $0 / 973$ & 11 \\
\hline Total & $0 / 629$ & $0 / 000$ & 295 \\
\hline
\end{tabular}

\section{Conclusion}

By considering and implementing of rural conducting schemes, the reformation of rural housing and issuing title indeed in about three decades some basic actions have been taken in organizing a space for rural activities in the rural environments of the country considered as effective actions to improve the physical development of rural. The rural conducting scheme has been considered in village as an organizational tool by providing an essential bed for development and growth. The physical and unphysical dimensions of these actions can be observed via considering and studying multidiscipline activities of housing foundation particularly in providing and implementing of rural conducting schemes, reformation of rural housing and issuing title indeed. The effects of housing foundation activities on sustainable development of rural housing can be strengthened and become sustainable through collecting data and presenting necessary information to manage schemes effectively.

The study results indicate that the results of housing foundation activities on the physical development of rural housing were studies based on analytical results of agent in four forms of factors: housing, pedestrian network, land use and environmental health. Based on these studies, it was concluded that there is a significant relationship between housing foundation activities and sustainable development of villages ( $\pi$ is less than 0.05 ). The direct and positive relationship has been considered to be 0.629 . Therefore; fourth hypothesis is confirmed via a $95 \%$ accuracy. The results of this study are in concordance with various 
studies accomplished by Ali Akbar Anabestani (2017), Ahamdi et al. (2017), Asghari et al. (2016), Sadeghi Bouger (2015), Shams-aldini et al. (2015), Fazli et al. (2014), Rezaee and Safa (2014), Anabestane et al. (2014), Zargar et al. (2014), Einali et al. (2014), Ekrami (2014), Golpaigani et al. (2014), Rezaee et al. (2013), Ejdehayi et al. (2012), Muhammadi Yeganeh et al. (2012), Behrouz Muhammadi et al. (2012), Anabestani (2012),Anabestani et al. (2012), Pourtaheri et al. (2011), Mobarak (2011), Bahrami (2011), Nasiri (2009), Samimi Sharmi (2009), Moradi et al. (2009) and Abedi (2006).

The study results suggested that the impact of housing foundation activities on the social development of rural habitations considered based on the agent's analytical results of these effects on five agents included population, education, participation, location and services. Based on these considerations, there is a significant relationship between housing foundation activities and social development of villages ( $\pi$ is less than 0.05 ). There is a 0.330 direct and significant relationship between housing foundation activities and the social development of rural habitation. Therefore; second hypothesis is confirmed via an accuracy of $95 \%$. The results of this phase are in concordance with the studies accomplished by Ahmadi et al. (2017), Anabsetani (2017), Sadeghi Bouger (2015), Rabiee et al. (2015), Shirini (2014), Fazli et al. (2014), Anabestani (2014), Ghasemi Ardehai et al. (2013), Muhammadi Yeganeh et al. (2013), Saeedi et al. (2013), Badri et al. (2013), Rostam Saberifar (2013), Ghorban Eslami et al. (2013), Roh-Allah Rezaei et al. (2013), Anabestane et al. (2013), Share pour (2013), Muhammadi et al. (2012), Nader Nastaran (2012), Ardehaie et al. (2012), Zarabi and Parikhani Eslami (2011), Maleki (2011), Pourtaheri et al. (2011), Moteie Langroudi (2010), Borzoo et al. (2010), Moteie Langroudi (2010), Moradi et al. (2009), Abedi (2006), Dadalpour Muhammadi (2000).

\section{Reference}

Abedi, Zargham. (2006), "The evaluation of issuing the title indeed of housing texture of all villages in the country, Babol Kenar district, Babool County, M.A thesis of Islamic Azad University of Tehran, Centre Tehran branch 
Ahmadi, Amir et al., (2017), "The implement of reforming and strengthening schemes of rural housing according to the rural life quality", Urmia County

Anabestani, Ali Akbar et al., (2012), "The evaluation of conducting scheme and the role played by scheme in physical development of village in the rural viewpoint", Jahrom County, Human Geography Studies, period 44, No.4

Anabestani, Ali Akbar et al., (2013), "The social and economic effects of conducting scheme in rural habitations of Dena County", Regional Planning Journal, year 3, No.9

Anabestani, Ali Akbar. (2009), "The evaluation of physical impacts of implementing of conducting scheme", First national conference on housing and physical development of village, Tehran

Anabestani, Ali Akbar. (2014), "The effective agents on the rural participation in implementing of conducting scheme", Khaf County, regional planning, Spring, No. 13

Anabestani, Ali Akbar. (2017), "The effects of implementing of renovation scheme of valuable textures on the development of rural habitations, Housing and environment journal, No.158

Ardehaiee, Ghasem Ali et al., (2012), "The impacts of strengthening the rural house in changes of rural life", Housing and Environment Journal, No.139

Asghari, et al., (2016), "The evaluation of quality of conducting scheme in case study villages of Zahak"

Azizpour, Farhad. et al., (2011), "The analysis of economic impacts of implementing of conducting scheme in the rural habitations of the country", Housing and environment journal, No.135

Badri, Seyed Ali. et al., (2013), "The evaluation of mind indices of life quality of rural district regions, Torkaman county, Geography and environmental planning, Year.24, No.2

Bahrami, Rahmat-Allah. (2011), "an analysis of rural housing situation in Kermanshah Province", Housing and environment journal, No.134

Borzou, Gholam Reza. et al., (2010), "The quality evaluation of implementing the conducting scheme in Karnachi village, Kermanshah"

Dalalpour, Muhammad Reza. (2000), "Housing planning", Samt publication, First edition

Einali, Jamshid et al., (2015), "The impacts of reformation the house in economic applied changes of rural housing, Shamshir rural district of Paveh County, Rural development and space economy Journal, No.14 
Ekrami, Gholam Reza. (2014), "The role of local materials in sustainable architecture in the environmental viewpoint of reforming the valuable rural textures in physical development of villages, The housing and environment of village Journal, No.156

Eslamirad, Ghorban et al., (2013), The analysis of providing, ratifying and implementing of rural conducting scheme and desirability in Mazandaran Province "

Eslamirad, Ghorban. Ghasemi (2013), "The analysis of providing, ratifying and implementing of rural conducting scheme and desirability in Mazandaran Province", First international conference on physical-location sustainable development of rural habitations, Ardebil, July

Golpaigani, abd-Ali et al., (2013), "Rural housing scheme and the effect on the hygienic and security indices of housing, Housing and environment journal, No.144

Haghpanah, Maryam. et al. (2009), "The physical implement of rural conducting scheme ", First national conference of rural housing and development, Tehran, The housing and environment of village Journal, No.134

Heidari Sareban, Vakil et al. (2013), "The impacts of conducting schemes in the villages of Bonab County, First national congress of physical-location sustainable development of rural settlements of Ardebil, July

Long, H., Zou, J., Pykett, J. and Li, Y. (2012), Analysis of rural transformation development in China since the turn of the new millennium.

Maleki, Saeed. (2011), "The situation of housing social indices in rural areas", Ahwaz County, Housing and environment journal, No.129

Mobarak, Umm Kulthum. (2011), "Physical-space impacts of conducting scheme, Pirkandi village of Khoy County, collected articles of third national geography congress, May on $24^{\text {th }}$ and $25^{\text {th }}$, Tehran

Monshizadeh, Rastegar. (2010), "The impact of governmental investment in improvement projects and schemes to stabilize the population of rural habitations of Varavi district, Fars Province

Moradi, Mahmud et al., (2009), "The impacts of conducting scheme on Haji Abad, Birjand County, collected articles of first national geography congress on housing and physical development of village, Zahedan, $30^{\text {th }}$ of September and $1^{\text {st }}$ of October

Moteie Langroudi, Seyed Hasan. (2010), "The results of conducting scheme on the environment of rural habitations" 
Moteie Langroudi, Seyed Hasan. (2010), "The role of housing reformation on the population`s potency and durability in Beihaq rural district

Muhammadi Yeganeh, Behrouz et al., (2012), "To determine the impacts of conducting scheme on improving life quality in rural areas", Korani rural district of Bijar County, Housing and environment journal, No.139

Muhammadi Yeganeh, Behrouz et al., (2013), "The role of housing reformation on improving life quality in rural areas", Mojezat rural district of Zanjan County, Housing and environment journal, No.158

Nasiri, Ismaeel. (2009), 'The effectiveness of conducting schemes of rural habitations in rural areas of Zanjan, First national congress on housing and physical development of village, Sistan and Baluchestan University, Zahedan

Nastaran. (2012), "The effects of rural conducting scheme on space-physical structure of villages in East Azerbayjan Province, villages of Shabestar, First national congress of stable space-physical development of rural habitations, Ardebil, July

Pourtaheri, Mahdi et al., (2011), "The physical development of rural habitations via a sustainable development", Eivan Gharb County, The housing and environment of village Journal, No. 137

Pourtaheri, Mahdi. Naghavi, Muhammad Reza. (2012), "The physical development of rural habitations via a sustainable development (concepts, theories and guideline)", The housing and environment of village Journal, No.137, spring of 2012, pp. 53-70

Rabieefar, Vali-Allah et al. (2015), "The analysis of impacts of rural conducting scheme on economic and social development of rural habitations of Hamedan Province, Regional planning journal, Chehel chay rural district of Golestan Province, Housing and environment journal, Year 5, No.17

Rahmani Fazli, Abd-AlReza. et al. (2015), "The analysis of evaluation of impacts of rural conducting scheme on rural habitations, Chehel chay rural district of Golestan Province, Housing and environment journal, No.159

Rezaei, Roh-Allah. et al. (2013), "The analysis of problems in implementing the conducting scheme in rural areas, Zanjan County, Housing and environment journal, No.142

Saberifar, Rostam. (2013), "The effective variants of success of rural conducting scheme", South Khorasan Province, Geographical studies Journal, No.102 
Sadeghi Bouger, Muhammad Shafi. (2015), "The effects of issuing title indeed of localities on developing rural habitations", Eqlid County, Geography and planning , Autumn

Saeedi, Abass. et al. (2013), "The renovation of housing, structural-applied changing in rural houses, villages environs of Zanjan County", Geography Journal, Year 9, No.1.

Samimi Sharmi, Reza. (2009), "The evaluation of effects of implementing the rural conducting scheme in Khamam district of Rasht", Housing and environment journal, No.127

Shams-Aldini, Ali. et al. (2015), "The evaluation of location-physical impacts of implementing the conducting scheme in Fathabad", Housing and environment journal, No.152

Shirini, Ali. (2014), "The effects of issuing title indeed of localities on the rural life quality", Ghochan County, Ministry of Science, Research and Technology of Ferdowsi University, Literature and human Science School

Statistical centre of Iran, (2016), "Population and housing census", General results of Ardebil Province. 